ПУБЛІЧНЕ УПРАВЛІННЯ Й АДМІНІСТРУВАННЯ ІНФОРМАЦІЙНО-КОМУНІКАЦІЙНИХ ТЕХНОЛОГІЙ У ДОСЯГНЕННІ УНІВЕРСАЛЬНОГО ПОКРИТТЯ МЕДИЧНИМИ ПОСЛУГАМИ

\title{
PUBLIC MANAGEMENT AND PUBLIC ADMINISTRATION OF INFORMATION COMMUNICATION TECHNOLOGY FOR ACHIVMENT UNIVERSAL HEALTH COVEREGE
}

у статті проаналізовано закордонний досвід використання інсрормаційно-комунікативних технологій у досягненні універсального покриття медичною послугою (Universal health coverage) та їхній вплив на публічне управління і публічне адміністрування охорони здоров'я в різних країнах. Розглянуті різні моделі використання телемедичних технологій для досягнення універсального покриття медичною послугою, а також їхній вплив на досяжність медичної допомоги в умовах пандемії. Узагальнено поняття універсального покриття медичною послугою, формалізації права на доступ до медичної допомоги різних верств населення та створення відповідних умов. Проаналізовано досягнення та ризики в основних напрямах універсального покриття медичною послугою. Констатовано вплив інформаційно-комунікаційних технологій на відповідь різних урядів на пандемію коронавірусної хвороби. Констатовано, що універсального покриття нині досягли Австралія, Канада, Фінляндія, Франція, Німеччина, Угорщина, Ісландія, Ірландія, Ізраїль, Нідерланди, Нова Зеландія, Норвегія, Португалія, Словацька Республіка, Словенія, Швеція, Швейцарія й Об'єднане Королівство. Усі ці країни активно використовують інфрормаційно-комунікативні технології та безпосередньо телемедичні технології. Визначено роль телемедицини в забезпеченні універсального покриття медичною послугою, а також розбудові й еволюції охорони здоров'я та громадського здоров'я. Визначено обсяг публічного адміністрування щодо використання телемедичних мереж для вирішення більшості питань щодо координації роботи закладів охорони здоров'я, доступності медичної послуги для всього населення та забезпечення рутинної планової допомоги. Особлива увага була приділена ролі кому нікаційних систем та телемедицини під час пандемії гострої респіраторної хвороби COVID-19, спричиненої коронавірусом SARSCoV-2, та подоланню ї̈ негативних наслідків для економіки та благополуччя населення. Розглянуті стратегії Сполучених Штатів Америки, Китаю, Південної Кореї та Європи щодо використання телемедичних мереж під час пандемії.

Ключові слова: універсальне покриття медичною послугою, телемедицина, інсрормаційно-комунікативні технології, охорона здоров'я, публічне адміністрування, публічне управління, комунікаційні технології в охороні здоров'я, електронні системи охорони здоров'я, e-Health, електронні медичні записи, цифрові системи охорони здоров'я.

In the article is given an analysis of the foreign experience of using information and communication technologies in achieving universal health coverage and their impact on public management and public administration of health care in different countries. Different models of using telemedicine technologies to achieve universal coverage by medical services, as well as their impact on the availability of medical care in a pandemic. The notion of universal coverage by medical service of formalization of the right to access to the medical care of different segments of the population and creation of appropriate conditions is generalized. The achievements and risks in the main directions of $\mathrm{UHC}$ are analyzed. The impact of ICT on the response of different governments to the coronavirus pandemic has been studied. It has been shown that Australia, Canada, Finland, France, Germany, Hungary, Iceland, Ireland, Israel, the Netherlands, New Zealand, Norway, Portugal, the Slovak Republic, Slovenia, Sweden, Switzerland, and the United Kingdom have so far achieved UHC. All these countries actively use information and communication technologies and direct telemedicine technologies. The role of telemedicine in the provision of $\mathrm{UHC}$, as well as the development and evolution of health care and public health, has been identified. The scope of public administration for the use of telemedicine networks to address most of the issues related to the coordination of health care facilities, accessibility of medical services for the entire population, and the provision of routine planned care has been determined. Particular attention was paid to the role of communication systems and telemedicine a during the pandemic of acute respiratory disease COVID-19 caused by the coronavirus SARS-CoV-2, and overcoming its negative consequences for the economy and welfare of the population. Strategies of the USA, China, South Korea, and Europe concerning the use of telemedicine networks during a pandemic are considered.

Key words: universal health coverage, Telemedicine, information and communication technologies, health care, public administration, public administration, communication technologies in health care, Electronic health care systems, e-Health, Electronic medical records, Digital health care systems.
Постановка проблеми. Система надання медичної допомоги в Україні залишається неефективною, що $€$ наслідком незбалансованої мережі закладів охорони здоров'я (далі - 303) (значне скупчення 303 у великих містах, дублювання функцій, погано напрацьовані або відсутні маршрути пацієнта, який потребує екстреної медичної допомоги, монопрофільні 303 тощо), а 3 іншого боку - критичний стан багатьох із цих закладів. 
Із 2019 р. укладанням Глобального договору щодо прогресу для універсального покриття в охороні здоров'я Україна взяла курс на розбудову медичної системи, яка забезпечує потреби кожного в доступній, якісній та необхідній медичній послузі без катастрофічних витрат із кишені.

Досягнення універсального покриття медичною послугою (далі - УПМП) є базою однієї із цілей сталого розвитку Організації Об'єднаних Націй (далі- ООН) - міцне здоров'я і благополуччя. Право на здоров'я $€$ одним із природних прав, а універсальне покриття медичною послугою сьогодні $€$ наріжним каменем покращення рівня дистрибуції сервісів, пов'язаних зі здоров'ям, на жаль, таке покриття становить тільки $50 \%$ [1].

Із 2011 р. поняття універсального покриття медичною послугою з'являється в багатьох державних та муніципальних програмах [2; 3], а у 2021 р. ВООЗ визначає відповідальністю уряду досягнення УПМП. Розвиток УПМП у світі базується не тільки на інфраструктурних змінах, які забезпечують фізичну доступність (створення нових амбулаторій, госпіталів, залучення медичного персоналу у важкодоступних місцях), але і залучення новітніх технологій, які здатні доставити медичну послугу пацієнту, незважаючи на його місцеперебування (телемедицина, електронні реєстри тощо). Проведена впродовж останнього часу робота була високо оцінена Генеральним директором ВОО3, а також зазначено, що «УПМП - це єдина найпотужніша концепція, яку може запропонувати громадськездоров'я» [4]. Після прийняття на себе обов'язку досягнення УПМП українській державі доведеться створити чітку та врівноважену політику щодо доступності та якості медичної послуги, що iї може отримати кожен без катастрофічних витрат із власної кишені. У розбудові УПМП необхідно врахувати найкращий науковий та практичний досвід інших держав у цьому напрямі.

Мета статті - вивчити практичний та науковий досвід у розробленні механізмів публічного управління розвитком, адміністрування, особливості використання інформаційно-комунікативних технологій у досягненні УПМП.

Аналіз останніх досліджень та публікацій. Питання УПМП тільки нещодавно з'явилось серед життевизначних питань в українській публічній політиці, отже, можна визначити, що обсяг вивчення цього питання у вітчизняній літературі залишається незначним.

Т.В. Семгіна й О.Ю. Осейчук розглядають універсальне покриття медичною послугою та розроблення системи соціальних гарантій в охороні здоров'я суто з боку широкої суспільно-політичної перспективи, не зачіпають питання організації надання медичних послуг, через використання інформативно-комунікативних технологій і поготів. Однак у статті розглянуто публічний підхід до адміністрування медичної послуги, адже зазначено, що те, що люди вважають соціально справедливим, повинно лягти в основу розроблення мінімальних гарантій для забезпечення універсального покриття медичною послугою [5].

Так, І.Л. Сазонець та І.Я. Зима у своєму дослідженні вивчають проблему доступу до служб медичної допомоги, особливо в сільській місцевості, рішення бачать у поширенні процесу добровільного об'єднання територіальних громад, яке, на їхню думку, повинно привести до поліпшення соціальної інфраструктури сіл, будівництву кращих доріг, придбання транспортних засобів, залученню кадрів до сільської місцевості [6]. Що є суто інфраструктурним підходом та зазвичай не забезпечує УПМП, а також потребує дуже серйозного фінансування.

І.В. Чеховська розглядає різні юридичні аспекти створення універсального доступу до медичної послуги, приділяє більше уваги саме державним гарантіям такого доступу, ніж забезпеченню ним операційно. У статті у висновках доводиться, що основним критерії подолання нерівності в доступі до медичних послуг і медикаментів виступає правове й економічне акцентування уваги відповідних урядів на формуванні і запровадженні медичного страхування, а також чіткого визначення джерел стабільного фінансування галузі, отже, забезпечення закупівлі достатньої кількості медичних послуг, виробів та технологій [7]. Більшість авторів розглядають досягнення універсального покриття медичною послугою суто в розрізі фінансування охорони здоров'я [8-10].

Отже, можна визначити, що під час дослідження моделей досягнення універсального покриття медичною послугою розглядається суто географічна доступність, а не інші можливості, як-от використання сучасних інформаційно-комунікативних технологій, не розглядається їх публічне адміністрування й управління з метою наближення медичної послуги до кінцевого споживача.

Виклад основного матеріалу. За визначенням ВООЗ, УПМП означає, що всі люди мають доступ до медичних послуг, які їм потрібні, коли та де вони потребують, без фінансових труднощів. Воно включає повний спектр основних медичних послуг - від зміц- 
нення здоров'я до профілактики, лікування, реабілітації та паліативної допомоги.

J. Ruger [11], дослідниця права на здоров'я та питань соціальної несправедливості у світі, запропонувала «парадигму можливостей забезпечення здоров'я», яка виходить з ідеї забезпечення вільного доступу до засобів, що здатні запобігти захворюваності та передчасній смерті. Ця парадигма є поєднанням філософських, соціальних та політичних підходів і практик, що можуть надати переконливі аргументи для всього суспільства і створити системи для досягнення кращих можливостей для здоров'я. Тому соціально справедлива охорона здоров'я - та, де в центрі системи перебуває забезпечення потреб пацієнта, вирішення його особистих проблем, пов'язаних зі здоров'ям

Важливим механізмом забезпечення соціальної справедливості міжнародні організації вважають «універсальне покриття» населення (universal health coverage), тобто виразно визначений обсяг послуг, доступний для всього населення. Універсальне покриття означає, що всі люди отримують якісні, необхідні їм базові сервіси, без ризику потрапити у фінансову скруту. Варто зазначити, що, попри ідеї «базовості», концепт передбачає чутливість до особистих потреб кожної людини, тому не йдеться про стандартний, однаковий для всіх «мінімум» медичних послуг. УПМП не тільки має бути спрямовано на зміну механізмів фінансування системи охорони здоров'я, але й охоплювати всі компоненти системи охорони здоров'я, що включає в себе системи надання медичних послуг, охорону здоров'я, медичні заклади та комунікаційні мережі, комунікацію та координацію між закладами, центральну електронну базу даних та інформаційні системи, механізми забезпечення якості, а також управління та законодавство. Держава для досягнення УПМП повинна забезпечити прогресивне розширення покриття медичними послугами пацієнтів, водночас створити запобіжники катастрофічним витратам домогосподарств на лікування.

Сьогодні 18 країн пропонують справжнє універсальне охоплення медичними послугами. Це такі країни, як: Австралія, Канада, Фінляндія, Франція, Німеччина, Угорщина, Ісландія, Ірландія, Ізраїль, Нідерланди, Нова Зеландія, Норвегія, Португалія, Словацька Республіка, Словенія, Швеція, Швейцарія та Об'єднане Королівство [12]. Однак і досі залишається багато країн, у яких медична послуга недоступна на досить значних територіях. Провести пряму кореляцію між доступністю та благополуччям країни неможливо. Так, у США й Австралії значна кількість населення, яке проживає у складнодоступних районах, і нині позбавлена адекватної медичної допомоги.

На думку багатьох дослідників, доцільно використовувати телемедичні мережі для вирішення більшості питань щодо координації роботи закладів охорони здоров'я, доступності медичної послуги для всього населення та забезпечення рутинної планової допомоги. Особлива роль комунікаційним системам та телемедицині відведена під час пандемії гострої респіраторної хвороби COVID-19, спричиненої коронавірусом SARS-CoV-2, та подоланню її негативних наслідків для економіки та благополуччя населення. Kenneth Okereafor і співавтори аналізують підходи, що були задіяні урядами в подоланні пандемії COVID-19, і виділяють чотири стратегії відповідно до країни або групи країн, які розробили той чи той вектор упровадження методів телемедицини: стратегію США, стратегію Китаю, Південної Кореї та Європи [13].

Деякі науковці в закордонній літературі протиставляють e-Health та телемедичну мережу [14] і визначають, що телемедицина немає такого широкого застосування, як технології e-Health.

Важливо зазначити, що в публічному адмініструванні у сфері охорони здоров'я основну роль відіграє не телемедична послуга, а телемедична мережа, яка являє собою організовану ієрархічну структуру в межах певної території (району, області тощо), яка складається з телеметричних центрів, пунктів і кабінетів, АРМів (як мобільних, так і стаціонарних), обов'язково включає підготовані кадри (медичні, технічні, управлінські).

На думку А.Ф. Мельника та співавторів [15], територіальній телемедичній мережі притаманні такі властивості, типові для публічного адміністрування:

1. Формування основи для аналізу і класифікації об'єктів управління залежно від цілей, які зіставлені з реальними об'єктивними можливостями.

2. Перетворення навколишніх умов завдяки встановленню з ними активної взаємодії.

3. Самоуправління життєдіяльністю і розвитком.

4. Адаптивність до умов природного й соціального буття.

5. Залежність від об'єктивних умов і чинників суспільної життєдіяльності.

Варто зазначити, що стратегія США, відповідно до досліджень Mike Miliard, насамперед спрямована на юридичне визначення та впорядкування сучасних регуляторних рамок щодо використання телемедицини [16]. 
Північноамериканські телемедичні моделі ("Telepresence", ANGELS, "TeleStroke"). У США немає єдиної телекомунікаційної моделі, тут реалізується різноманітна телемедична діяльність із включенням лікарів, медичних сестер, громадських організацій. Широко використовується «домашня телемедицина», коли громадянин має необхідні телеметричні засоби, сам вимірює свої життєві показники та відправляє їх своєму лікареві [17].

Як уже зазначено вище, у деяких штатах можуть діяти окремі моделі телемедицини, наприклад в Арканзасі діє модель ANGELS, ціль якої - регіоналізація спеціалізованої медичної допомоги в окремих сферах через надання доступу до експертних висновків. ANGELS складається з п'яти елементів, як-от: телемедична і клінічна мережа, навчальна й методична інформація для провайдерів медичної допомоги, служба менеджменту клінічних випадків, цілодобовий call-центр і доказові посібники (інструкції, протоколи). В основі закладені широкоформатні відеоконференції та досить дорогі комп'ютерні робочі станції зі спеціальним діагностичним устаткуванням (ультразвукові сканери) [18].

Моделі "TeleStroke" [19] та "Telepresence" [20] спрямовані на надання допомоги в ухваленні клінічного рішення лікарями загального профілю (терапевти, лікарі невідкладних станів) в екстрених ситуаціях (інсульт, травма) за допомогою консультацій фахівців із високоспеціалізованих медичних центрів. Ці моделі включають в себе телемедичне асистування, контроль та керівництво.

Yankai Zhai та співавтори стверджують, що китайська стратегія спрямована на максимальне розширення практичного використання телемедицини для надання медичної допомоги пацієнтам [21].

У Сполучених Штатах клініцисти й адміністратори виступають за термінове внесення змін у національну програму медичного страхування (Medicare), державну програму медичної допомоги (Medicaid) та програму приватного страхування для забезпечення можливості лікарям проводити телемедичні консультації напряму для пацієнтів і отримувати за це оплату. Відповідно до цих потреб Американська академія педіатрії розробила гайдлайни та пропозиції щодо політики оплати за телемедичні консультації в умовах COVID-19, у яких описані необхідні зміни, потрібні для того, щоб подолати бар'єри з надання медичної консультації за допомогою телемедицини. Для підтримки змін багато регуляторних заходів будуть послаблені найближчим часом [22].
Європейська модель базується на рекомендаціях, запропонованих Національною службою здоров'я Великої Британії (National Health Service, NHS), насамперед спрямована на обслуговування віддалених лікарень і населених пунктів вузькоспеціалізованими лікарями (кардіолог, невролог, цитолог тощо). Здебільше фахівці залучаються для вирішення складного клінічного завдання. Основою моделі виступає мережа Інтернет, за допомогою стандартних методів передачі інформації (e-mail, MMS тощо). Технології та фахівці в цій моделі підібрані за конкретними клінічними завданнями [23].

Trisha Greenhalgh та співавтори визначають, що стратегія NHS із використанням методу телемедицини під час коронавірусної хвороби насамперед спрямована на виявлення нових випадків та зменшення відвідування лікарень для полегшення навантаження на них. Так, NHS пропонує вебсервіс, на якому можна перевірити наявність симптомів під час проходження опитування на сайті . Після проходження опитування пацієнту надається валідована відповідь, чи має він ознаки COVID-19, та запропоновані подальші дії. Для тих, хто бажає отримати загальні відповіді та рекомендації стосовно COVID-19, працює відповідна телефона лінія [24].

Окрім того, на думку Robert Turer і співавторів, використання телемедицини дасть можливість значно зменшити економічне навантаження на систему охорони здоров'я, адже під час кожного візиту до цих пацієнтів необхідно було б використовувати засоби індивідуального захисту (далі - ЗІЗ), такої потреби не має в разі телемедичних консультацій [25].

Важливим питанням є ведення пацієнтів, які залишилися вдома або перебувають на режимі самоізоляції після контакту з пацієнтом, хворим на COVID-19. Багато клінік (Jefferson Health, Mount Sinai, Kaiser Permanente, Cleveland Clinic, and Providence) уже впроваджують телемедичні системи, які дозволяють спостерігати пацієнта вдома.

Kenneth Okereafor та співавтори визначають, що особам, які перебувають у самоізоляції, варто запропонувати перелік сценаріїв телемедичного консультування: спостереження для асимптоматичного перебігу, спеціалізовані медичні консультації для пацієнтів з неускладненим та легким перебігом, медичні сервіси для лікування пацієнтів, які не можуть дістатися до спеціалізованої та високоспеціалізованої допомоги, та навіть спостереження за допомогою геолокації за особами, які повинні перебувати в обсервації у зв'язку з поверненням із країн зі спалахами COVID-19 [13]. 
Окрім того, Hyunghoon Cho та співавтори відмічають високу важливість можливості відстежувати слід мобільного телефону пацієнта з COVID-19 для виявлення контактів та ризиків зараження. Автори проаналізували різні мобільні додатки та стратегії і зазначають, що натепер є багато питань, адже безперечні надбання з боку протиепідемічних заходів та виявлення нових випадків інфікування можуть бути нівельовані серйозними порушеннями придатності [26].

У країнах із низьким доходом, переважно в південноафриканських, можна спостерігати постійне нагромадження цифрової медичної інформації та безперервне навчання через Інтернет із широким використанням вебтрансляцій наукових конференцій, електронних бібліотек. Метою проєкту створення мережі $€$ залучення талановитих професіоналів на роботу у віддалені райони Африки. Важливою особливістю $€$ використання як засобів Інтернету, так і відедоконференцій, із залученням не тільки лікарів, а і медичних сестер. Окрім того, для надання консультацій широко залучені іноземні експерти у складних випадках [27]. Досить поширена так звана Low-cost telemedicine/low recourse settings («телемедицина в умовах обмежених ресурсів»), зазвичай це не налаштована мережа, яка врівноважена законодавчою базою, а спорадичні використання дешевих засобів передачі інформації (мобільний інтернет, різноманітні месенджери), навіть без спроб захистити особисті данні. Іноді для передачі інформації може бути використаний радіозв'язок. Незважаючи на максимальну дешевизну таких комунікацій, ця модель не має впливу на адміністрування сфери охорони здоров'я у відповідних країнах.

Незалежно від країни, нині телемедичні мережі не так широко впливають на національну стратегію розвитку охорони здоров'я, здебільшого мають досить обмежений характер (телемережа для надання допомоги в разі інфаркту міокарда, інсульту, орфанних захворювань тощо). Телекомунікація в медичному застосуванні передбачає передачу медичної інформації між парою передавачів і приймачів. Інформація може бути в основному вигляді, наприклад у лікаря, який надає усну інструкцію для догляду за хворим, або в дуже складному форматі, де великі дані допомагають лікареві в ухваленні рішень. Відповідно до літературних джерел, успішне втілення телемедичної мережі вимагає зміни підходу до менеджменту розвитку цих мереж. У результаті проведеного аналізу літературних джерел можна зазначити такі обов'язкові напрями: телемедичні програми повинні обиратись прагматично, а не відповідно до «емоційного» запиту. Цей принцип означає, що необхідно витрачати ресурс на вирішення справді соціально значущих проблем (як-от захворювання серцево-судинної системи, які стоять на першому місці серед причин смертності в усьому світі), а не намагатись вирішити рідкісні проблеми (первинні імунодефіцити) втратою дорогого ресурсу.

Телемедичні додатки повинні бути створені в манері, дружній до користувача. Багато клініцистів та чиновників уникають використання комунікативних технологій, не бажають навчатись використання комп'ютерної техніки. Створення телемедичних центрів - усе ще прерогатива людей зі знанням комп'ютера, хоча б на рівні користувача, передусім тому робота в таких центрах може бути важкою для людей, клініцистів та чиновників, які ніколи не вивчали комп'ютерної грамотності. Отже, з одного боку, необхідно створювати максимально простий і доступний інтерфейс, а з іншого - користувачів телемедичних мереж необхідно тренувати як у професійному, так і в технічному плані.

Висновки. Невід'ємною частиною «електронного здоров'я» стали системи телемедицини. Варто зазначити, що зараз складно виділити один конкретний тип системи телемедицини, однак усе ще можна виокремити: західноєвропейську, регенсбурзьку, RAFT, північноамериканську, "low-cost telemedicine/low resourse settings" та «два острови». В Україні нині переважає змішана модель телемедицини з вираженими ознаками регенсбурзької моделі. Сутність цієї моделі полягає у використанні дешевих технологій із метою максимального доступу до телемедичної послуги кожним пацієнтом. Вагомим мінусом цієї моделі виступає велика кількість вразливостей захисту персональних і адміністративних даних.

Для публічних управлінців і адміністраторів, зокрема й адміністраторів медичних закладів, використання інформативно-комунікативних технологій - це доступність лікарів скрізь і одночасно; скорочення витрат; формування системи громадського здоров'я, ліквідація медичної неграмотності, коли населення активно піклується про власне здоров'я та здоровий спосіб життя; системне проєктування команди, встановлення та підтримка відносин; покращення ефективності комунікацій; залучення штучного інтелекту до лікувальної практики; покращення загальної якості послуг охорони здоров'я; регулювання непередбачуваних впливів на динаміку робочого процесу й охорону здоров'я; формування системи комунікації громадського здоров'я (масові та мовленнєві зв'язки, медична освіта, 
маркетинг, журналістика, зв'язки із громадськістю, психологія, інформатика, епідеміологія); формування громадської охорони здоров'я (охорона здоров'я через зміни на всіх рівнях впливу шляхом підвищення обізнаності, рівня знань, формування настроїв та зміни поведінки населення); формування комунікації участі у здоров'ї; надання медичних послуг та медичної допомоги з використанням IKT; обробка, збереження, обмін інформацією.

Окремою темою виступають питання розвитку та впровадження телемедицини під час пандемії COVID-19. Тут зазначено низку істотних переваг: використання телемедицини зменшує навантаження на відділення екстреної та невідкладної допомоги та на 303 загалом, покращує логістику пацієнта, підвищує безпеку медичних працівників, зменшує економічне навантаження, завдяки меншій потребі у використанні заходів індивідуального захисту, можливості навчання медичного персоналу через телемедичну мережу.

Визначено вдалий досвід застосування телемедичних мереж у боротьбі з пандемією COVID-19, адже в багатьох країнах ці мережі вже сформовані та добре скоординовані.

Різні країни в основу стратегії використання телемедичних мережпокладають вирішення різних проблем. У Сполучених Штатах Америки основне питання розвитку телемедичної мережі - законодавча та нормативна легалізація методу телемедичної консультації, прописування алгоритмів, що дають змогу лікарю отримувати оплату за телемедичну консультацію в межах програм медичного страхування, полегшення вимог щодо особистої інформації. Китайська стратегія використання телемедичних методів спрямована на розширення технічних можливостей надання консультацій пацієнтам. Європейська модель спрямована на виявлення нових випадків та зменшення відвідування лікарень.

Серед проблем, які вирішують телемедичні консультації, можна визначити п'ять великих груп: сортування пацієнтів і ухвалення рішення щодо їх госпіталізації до лікарень, визначених для пацієнтів із COVID-19 або до інших лікарень; надання допомоги та консультацій пацієнтам із COVID-19 на самоізоляції та лікуванні пацієнта в домашніх умовах; координація між лікарнями та забезпечення консультації спеціалістів вузького профілю; навчання медичного персоналу щодо протиепідемічних заходів та роботи 3 пацієнтом із COVID-19; забезпечення рутинних консультацій пацієнтів із неекстреною патологією, хронічних та паліативних пацієнтів.

Отже, перспективи подальших розвідок будуть стосуватись більш вузького дослі- дження значення інформаційно-комунікаційних технологій у забезпеченні доступної, якісної та своєчасної допомоги пацієнтам, ролі ІКТ у розвитку національної стратегії охорони здоров'я та публічного здоров'я України.

\section{ЛІТЕРАТУРA:}

1. Carissa Etienne, Asamoa-Baah Anarfi, Evans David B. Health systems financing: the path to universal coverage. World Health Organization, 2010.

2. The Bangkok Statement on universal health coverage. The Lancet. 2012. URL: https://doi.org/10.1016/S0140-6736(12)60212-8

3. Mexico City Political Declaration on Universal Health Coverage. 2012. URL: http://www.who.int/ healthsystems/topics/financing/

4. Making fair choices on the path to universal health coverage. Final report of the WHO Consultative Group on Equity and Universal Health Coverage. WHO. 2012. URL: https://apps.who.int/iris/bitstream/han dle/10665/112671/9789241507158_eng.pdf.

5. Семигіна Т.В., Осейчук О.Ю. Зменшення несправедливості в охороні здоров'я: популізм, прагматизм чи суспільний консенсус? Наукові записки Національного університету «Києво-Могилянська академія». 2016. Т. 186. С. 38-42.

6. Сазонець І.Л., Зима І.Я. Визначення проблем та основних напрямів ресормування системи охорони здоров'я України. Державне управління: удосконалення та розвиток. 2018. № 12.

7. Чеховська І.В. Зарубіжний досвід правового забезпечення реалізації проєктів єдиного медичного простору. Ірпінський юридичний часопис. 2020. № 2(4). C. 31-41.

8. Петрушка О.В. Світовий досвід фрінансового забезпечення охорони здоров'я: уроки для України. 2016.

9. Іванчук О.М. Добровільне медичне страхування: зарубіжний досвід для України. Актуальні проблеми державного управління. 2019. № 2(56). C. 177-182.

10. Шевченко М.В., Карамзіна Л.А., Дорошенко О.О. Фінансування системи охорони здоров'я: зарубіжний та вітчизняний досвід. Україна. Здоров'я нації. 2012. № № 2-3. С. 97-100.

11. Ruger J. Health and social justice. London ; NewYork : Oxford University Press, 2009. 276 c.

12. Organization for Economic Cooperation and Development. URL: http://www.oecd.org/els/healthsystems/measuring-health-coverage.htm

13. Okereafor K., Adebola O., Djehaiche R. Exploring the potentials of telemedicine and other noncontact electronic health technologies in controlling the spread of the novel coronavirus disease (COVID-19). International journal in IT \& Engineering. 2020. 8. № 4.

14. DellaMea $V$. What is e-health: the death of telemedicine? Journal of medical Internet research. 2001. № 3.

15. Мельник А.Ф., Оболенський О.Ю., Васіна А.Ю. Державне управління. Київ : Знання, 2009. 582 с.

16. Miliard M. Congress waives Telehealth restrictions for coronavirus screening Healthcare 
IT News, 2020. URL: https://www.healthcareitnews. com/news/congress-waives-telehealth-restrictionscoronavirus-screening

17. Clements M.A., Staggs V.S. A Mobile App for Synchronizing Glucometer Data: Impact on Adherence and Glycemic Control Among Youths With Type 1 Diabetes in Routine Care. J Diabetes Sci Technol. 2017. № 11. P. 461-467.

18. Time Trends and Payer Differences in Lengths of Initial Hospitalization for Preterm Infants, Arkansas 2004-2010 / S. Ounpraseuth, et al. American Journal of Perinatology. 2014. № 1. P. 33-42.

19. Expansion of Telestroke Services Improves Quality of Care Provided in Super Rural Areas / D. Zhang et al. Health Affairs (Millwood). 2018. № 12. P. 2005-2013.

20. Using telepresence for social connection: views of older people with dementia, families, and health professionals from a mixed methods pilot study $/$ W. Moyle et al. Aging Ment Health. 2018. № 17. P. 1-8.

21. From Isolation to Coordination: How Can Telemedicine Help Combat the COVID-19 Outbreak? I Y. Zhai et al. MedRxiv. 2020.
22. Pediatric Telehealth in the COVID-19 Pandemic Era and Beyond / Alison Curfman et al. Pediatrics. 2021. № 148 (3). URL: https://doi.org/10.1542/ peds.2020-047795

23. Kamsu-Foguem B. Systemic modeling in telemedicine. La Recherche Européenne en Télémédecine. 2014. № 3. P. 57-65.

24. Greenhalgh T., Koh G.C.H., Car J. COVID19: a remote assessment in primary care. Bmj. 2020. P. 368.

25. Electronic personal protective equipment: a strategy to protect emergency department providers in the age of COVID-19 / R.W. Turer et al. Journal of the American Medical Informatics Association. 2020.

26. Cho H., Ippolito D., Yu Y.W. Contact tracing mobile apps for COVID-19: Privacy considerations and related trade-offs. arXiv preprint arXiv. 2003. 11511. 2020.

27. Seven years of telemedicine in Médecins Sans Frontières demonstrate that offering direct specialist expertise in the frontline brings clinical and educational value / S. Delaigue et al. J Glob Health. 2018. № 8(2). 